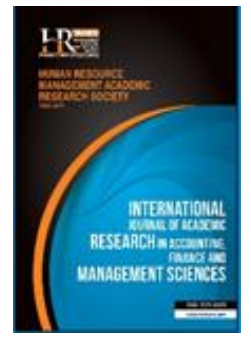

International Journal of Academic Research in Accounting, Finance and Management Sciences

Vol. 8, No.2, April 2018, pp. 113-125

E-ISSN: 2225-8329, P-ISSN: 2308-0337

(C) 2018 HRMARS

www.hrmars.com

To cite this article: Alqatamin, R.M. (2018). Capital Structure and CEO's Personal Characteristics: Evidence from Jordan, International Journal of Academic Research in Accounting, Finance and Management Sciences 8 (2): 113 125.

\title{
Capital Structure and CEO's Personal Characteristics: Evidence from Jordan
}

\author{
Rateb Mohammad ALQATAMIN \\ Accounting Department, Business Faculty, Tafila Technical University, Jordan, P.O. Box 179, Tafila 66110 \\ E-mail: rqatamin@ttu.edu.jo
}

\begin{abstract}
The aim of this study is to examine the effect of the CEO's personal characteristics (overconfidence, age and gender) on the capital structure choices among non-financial Jordanian companies over the period 2008-2013. We use panel data for 201 non-financial companies listed on the Amman Stock Exchange (ASE). The results of our study reveal that CEOs' overconfidence and gender are positively and significantly related to the leverage ratio as a proxy for capital structure. However, age is negatively and significantly associated with capital structure. The findings of the study should be of interest to policymakers, regulators and academics regarding the impact of CEO characteristics on the capital structure not only in Jordan but also in other developing countries. Further, the findings of this study are likely to be of interest to investors, since we introduce new empirical evidence about companies' capital structure in Jordan. Our study contributes to research into capital structure by examining another dimension, that is, the effect of the CEO's personal characteristics (age and gender), which has not been previously investigated in capital structure decisions and thus provides new empirical evidence in this area.

Key words Capital Structure, CEO's Overconfidence, Gender Diversity, Amman Stock Exchange, Jordan

Received: 15 May 2018 (c) The Authors 2018

Revised: 30 May 2018 Published by Human Resource Management Academic Research Society (www.hrmars.com)

Accepted: 05 Jun 2018 This article is published under the Creative Commons Attribution (CC BY 4.0) license. Anyone may reproduce, distribute, translate and create derivative works of this article (for both commercial and noncommercial purposes), subject to full attribution to the original publication and authors. The full terms of this license may be seen at: http://creativecommons.org/licences/by/4.0/legalcode
\end{abstract}

\section{Introduction}

How firms make their capital structure decisions has been one of the most extensively researched areas in corporate finance (Harris and Raviv, 1991; Zeitun and Tian, 2007). Since the seminal work of (Myers and Majluf, 1984) on the irrelevance of capital structure in investment decisions, a rich theoretical literature has emerged that models a firm's capital structure choices employing different frameworks. Several theories such as trade-off theory rely on traditional factors such as tax advantage and potential bankruptcy cost of debt, while others use asymmetric information or a game theoretical framework in which debt or equity is used as a signalling mechanism or strategic tool (Ross, 1977; Myers and Majluf, 1984; Desai et al., 2005). Many of these theories have also been empirically tested, yet there is little consensus on how firms choose their capital structure (Lemmon et al., 2014). Our paper examines the role of CEOs' personal characteristics on the choice of capital structure. A large and growing body of research in experimental psychology reports that people frequently depart from this traditional paradigm; people tend to be excessively optimistic and overconfident. That is, they predict that favourable future events are more likely than they actually are, and they believe that they have more precise knowledge about future events than they actually have (Skala, 2008; Libby and Rennekamp, 2012). 
Top executives are particularly likely to possess certain personality traits which, it is often argued have some bearing on corporate decision making. Consequently, it is important to understand how these managerial traits affect corporate outcomes and hence shareholders' welfare. Most of the studies on the relationship between capital structure and CEO's individual characteristics focus on developed countries (e.g. Malmendier et al., 2011; Cronqvist et al., 2012), although, the world economic structure varies and the situation of developing countries significantly affects global economic recovery. Companies in Jordan, as an emerging market, are gaining considerably more attention from the Middle East and Arab countries. Considering this bias, we examine the relationship between capital structure and CEO's characteristics in the context of the Middle East and Arab countries, and particularly among non-financial companies listed on the Amman Stock Exchange (ASE). Our study examines the impact of CEO's personal characteristics on capital structure; this is differs from prior studies which attempted to explain the relationship between capital structure and different factors such as firms' performance (Ahmad et al., 2012) or owners' equity return (Salawu and Agboola, 2008a). A review of previous studies does not clarify how CEO's characteristics affect the capital structure. These limitations provide the motivation for the present study to bridge this gap in the literature. Thus, the aim of this study is to extend the current body of literature by examining the effect of CEOs' personal characteristics (overconfidence, age and gender) on the capital structure choices among non-financial Jordanian companies over the period 2008-2013, all of which are often cited as important CEO's characteristics for corporate decisions (Frank and Goyal, 2007; Li et al., 2017). The results of our study reveal that overconfidence and gender are positively and significantly related to the leverage ratio as a proxy for capital structure. However, age is negatively and significantly associated with capital structure. Thus, this study contributes to the capital structure literature by examining another dimension, that is, the effect of CEOs' personal characteristics, which has not been previously investigated on capital structure decisions, and provides new empirical evidence in this area. In particular, our evidence strongly complements that of Morellec (2004), implying that managerial dominance is a significant determinant of capital structure policy. Furthermore, our study contributes to the literature adding interesting empirical evidence to the debate over whether CEO matter to company outcomes and ultimately to overall corporate value.

\section{Literature review}

In corporate finance, capital structure appears to be an important aspect of financing choice since it strongly affects the equity return and risks related to ownership as well as the market value of the shares (Frank and Goyal, 2009). However, the wrong mix of finance may cause serious damage affecting the performance and survival of the business enterprise (Thomas et al., 2014). As highest ranking executive, and the most powerful, the CEO's characteristics are likely to affect corporate decision making (Carpenter et al., 2004). Furthermore, the CEO influences investment and financial decisions, his or her characteristics and risk preference influence the corporate leverage policy (Chen et al., 2014). Risk-preference managers are more likely to take advantage of the tax effect of debt interest to conduct higher liability financing; whereas the risk adverse managers tend to hold more cash to avoid financial pressures of debt, the reputation damage. In response, researchers have started to examine individual characteristics, especially those of the CEO (e.g. Huang and Kisgen, 2013; Serfling, 2014; Faccio et al., 2016). Faccio et al. (2016) and Li et al. (2017) highlight the impotence of managers in capital structure. For example, Faccio et al. (2016) document that female CEOs tend to associated with less risky firms which are less leveraged, have less volatile earnings, and are more likely to survive. Similarly, Armstrong et al. (2010) suggested that CEOs' characteristics can play an important role in capital structure choice, as the CEOs are appointed to meet the expectations of shareholder to maximize the firm's value. Similarly, Malmendier et al. (2011) stated that the CEO's characteristics have a significant influence on corporate financing decision. Whereas CFOs have the first responsibility to make financing decision, it is the CEOs who approve whether to undertake external financing or use cash and riskless debt. Salawu and Agboola (2008b) documented that corporate capital structure is considered as an important management decision as it greatly influences the owners' equity return, owners' risk as well as market value of the shares.

Recently, the corporate finance literature has come to consider the effect of corporate managers' personality traits on capital structure choices (e.g. Malmendier et al., 2011; Cronqvist et al., 2012; Faccio et 
al., 2016; Li et al., 2017). According to Hambrick (2007), the senior manager's personal characteristics affect judgement and decision making, and among these characteristics is overconfidence. Overconfidence is the tendency of individuals to consider them above average (Svenson, 1981; Alicke, 1985; Kruger, 1999). Langer (1975), defines overconfidence as "an overestimation of one's own abilities and outcomes relating to one's personal situation". The overconfident CEO can significantly influence debt/equity choice, and he/she will choose to issue more debt than their rational peers do (Alqatamin et al., 2017). This occurs because the biased CEO believes that the firm is less likely to experience financial distress than is actually the case (Hackbarth, 2008). Overconfident managers generally maintain a higher liability level in debt financing as they believe this can provide considerably more advantage for the shareholders (Graham et al., 2013). However, Malmendier et al. (2007) indicate that overconfident managers use a higher level of debt than rational managers. Thus, he/she will underestimate the expected cost of bankruptcy and will take on more debt to exploit its tax benefits. Weinstein (1980) and Alicke (1985) earlier reported that overconfidence is often seen in managers (Cooper et al., 1988; Landier and Thesmar, 2009). The influence of CEOs' overconfidence on corporate decisions has received significant attention in the academic literature. For example, Malmendier and Tate (2008) and Frank and Goyal (2009) documented that it might have a significant influence on the variation in leverage across companies. Fairchild (2010) investigated the effect of managerial overconfidence on financing decisions, using two models: the agency problem to free cash and the agency problem and managerial shrinking. However, in both cases the effect of overconfidence is ambiguous. Oliver (2009) examined the relationship between CEOs' overconfidence and leverage ratio among the 500 largest US firms. The results concluded that managers tend to issue more debt when they are categorized as overconfident. However, Tomak (2013) investigation of the relationship between overconfidence and capital structure in 117 Turkish manufacturing firms, 2002 to 2011, found that the relationship between the variables was ambiguous, since there was insufficient evidence that overconfident managers were more likely to use a higher level of debt.

Taylor (1975) noted that managerial decision making and performance vary with age and decisionmaking experience. Previous empirical studies have offered conflicting predictions as to how age affects risk-taking behavior and leverage. One strand of literature argues that younger CEOs use more leverage and another argues the opposite to be true. Serfling (2014) documented that CEOs' characteristics such as age are associated with debt financing behaviour, and that older CEOs invested less than younger ones in pursuing a quieter life. Results of the study support the argument that older managers are likely take on less risk since they often think about the past, while young managers are more likely to think about the future (Chen et al., 2014). Bertrand and Schoar (2003) and Frank and Goyal (2007) also argue that older CEOs are linked with conservative behaviour due to the experience of the past, but that younger CEOs are inclined to be radical because of their expectation of the future. Consequently, the former avoids debt financing, although their study does not find statistically significant evidence to support their argument.

A third demographic characteristic examined in the literature is the CEO's gender (Richardson et al., 2016). For example, Singh and Zammit (2000) investigated the impact of gender on the international capital structure. It has been argued that female CEOs lose more than their male counterparts in unstable macroeconomic conditions. Males are more concerned with financial benefits and a successful profession, and are more likely to break the law and rules to attain competitive success, while females learn more towards appropriate relationship and helping people, and are less likely to engage in unethical issues (Mason and Mudrack, 1996). Huang and Kisgen (2013) revealed that companies run by male CEOs are more likely to use debt than companies run by female CEOs. Graham et al. (2013) showed that companies managed by male CEOs have more debt than those with female CEOs. Likewise, Faccio et al. (2016) analyzed 21 countries between 1999 and 3009 and found a statistically significant relationship between female CEOs and leverage ratio. The upper echelon theory assumes that males are overconfident and risk-tolerant; while females, on the contrary, are more conservative and risk-averse (Huang and Kisgen, 2013). The same theory describes female CEOs as more conservative, preferring equity financing to debt financing (Frank and Goyal, 2007). To put it another way, female CEOs are inherently conservative ad risk-averse and, as a result, are more likely to employ less debt financing (Huang and Kisgen, 2013; Faccio et al., 2016). Therefore, based on the previous argument and findings of the studies mentioned above, we propose the following hypotheses: 
H1: There is a positive relationship between CEO overconfidence and debt level among non-financial Jordanian companies.

H2: There is negative relationship between CEO age and debt level among non-financial Jordanian companies.

H3: The level of debt is positively associated with the presence of male CEOs among non-financial Jordanian companies.

\section{Methodology of research}

\subsection{Data Source and Sample}

The study collected data from the Amman Stock Exchange (ASE), which lists 270 companies divided into the financial, industrial and service sectors. All financial companies $(n=42)$ were excluded from the initial sample due to their unique characteristics and specific regulatory framework (Al-Akra and Hutchinson, 2013; Athanasakou and Hussainey, 2014; Alzoubi and Alzoubi, 2016). 27 firms with missing data were also removed from the initial sample (Athanasakou et al., 2009; Katmun, 2012; Alqatamin et al., 2017). Thus, the final sample consisted of 201 companies covering the fiscal years 2008-2013, with 1,206 firm-year observations, as presented in Tables 1 and 2. This study adopted the six-year period from 2008 to 2013, since the financial crisis started in 2008 and triggered different reforms and corporate governance practices in the same year in Jordan (Alqatamin et al., 2017).

Table 1. Description of sample

\begin{tabular}{|c|c|c|c|c|c|c|c|}
\hline Description & 2008 & 2009 & 2010 & 2011 & 2012 & 2013 & Pooled \\
\hline Initial Sample & 270 & 270 & 270 & 270 & 270 & 270 & 1620 \\
\hline \multicolumn{8}{|l|}{ Excluded: } \\
\hline Financial industries & 42 & 42 & 42 & 42 & 42 & 42 & $(252)$ \\
\hline Non-financial industries & 228 & 228 & 228 & 228 & 228 & 228 & 1326 \\
\hline \multicolumn{8}{|l|}{ Industries with fewer than six firms } \\
\hline Health Care & 4 & 4 & 4 & 4 & 4 & 4 & 24 \\
\hline Technology and Communication & 1 & 1 & 1 & 1 & 1 & 1 & 6 \\
\hline Media & 2 & 2 & 2 & 2 & 2 & 2 & 12 \\
\hline Paper and Cardboard & 3 & 3 & 3 & 3 & 3 & 3 & 18 \\
\hline Utilities and Energy & 3 & 3 & 3 & 3 & 3 & 3 & 18 \\
\hline Printing and Packaging & 1 & 1 & 1 & 1 & 1 & 1 & 6 \\
\hline Tobacco and Cigarettes & 2 & 2 & 2 & 2 & 2 & 2 & 12 \\
\hline Glass and Ceramic Industries & 1 & 1 & 1 & 1 & 1 & 1 & 6 \\
\hline \multicolumn{8}{|l|}{ (102) } \\
\hline Firms with unavailable data & 10 & 10 & 10 & 10 & 10 & 10 & $(60)$ \\
\hline Final Sample & 201 & 201 & 201 & 201 & 201 & 201 & 1206 \\
\hline
\end{tabular}

Table 2. Final distribution of the sample by industry

\begin{tabular}{lcc}
\hline Description & Number & Percentage \\
Educational services & 26 & $12.93 \%$ \\
Hotels and tourism & 38 & $18.90 \%$ \\
Transport & 23 & $11.44 \%$ \\
Commercial services & 41 & $20.39 \%$ \\
Pharmaceutical and medical industries & 12 & $5.97 \%$ \\
Chemical industries & 15 & $7.46 \%$ \\
Food and beverages & 17 & $8.45 \%$ \\
Mining and extraction industries & 14 & $6.96 \%$ \\
Engineering and construction & 6 & $2.98 \%$ \\
Textiles, leather and clothing & 9 & $4.47 \%$ \\
\hline Total & & $\mathbf{2 0 1}$ \\
\hline
\end{tabular}

Source: (JSC 2015) 


\subsection{Data Collection}

Data were collected from the annual reports published in the years 2008-2013. Each report was scanned manually. Most are published annually on company websites. Most firms release their annual reports within first the quarter of the following financial year. Annual reports are considered more easily comparable among companies than other less formal communication channels such as press releases or direct contact analyses (Chang and Most, 1985; Alqatamin et al., 2017). Furthermore, to cover some missing financial information in the annual reports, the websites of the Securities Depository Centre (SDC), the ASE itself and the OSIRIS database were used as additional sources.

\subsection{Measuring of Variables}

Leverage is the dependent variable in our regression model. We measure the leverage by book value of total long-term debt divided by book value of total assets, using the data obtained from financial statements for each company (Wen et al., 2002; Zeitun et al., 2007; Olokoyo, 2013). Following previous studies (Davidson III et al., 2007; Skalpe, 2007; Cornett et al., 2008; Cornett et al., 2009; Andriosopoulos et al., 2013; Lin et al., 2014), this study measured the CEO's age as the difference between date of birth and the years of the study period. The CEO's gender is a dummy variable with the value of 1 if the CEO is male and 0 if female (Skalpe, 2007; Yu et al., 2010; Andriosopoulos et al., 2013; Yim, 2013).

To measure overconfidence, we use the Net Buyer method, which focuses on option-holding behaviour and stock purchases. Following Malmendier and Tate (2008) and Alqatamin et al. (2017), we consider overconfidence as a reflection of the degree to which CEOs fail to minimize the degree to which their personal wealth is exposed to company-specific risk. This measurement is based on the tendency of CEOs to purchase extra stock in their own company despite their own personal wealth being exposed to a high level of company risk to. This is because overconfident CEOs overestimate the prospective returns on their own projects in the belief that the company stock price will rise more under their leadership than would normally be expected. If the CEO has such overconfident belief, he/she tends to buy up stock in the company in the hope of profiting from the expected future gains. Thus, we defined the CEO as overconfident based on the Net Buyer Measure if he/she is a net buyer of his/her own-company stock in the initial six years of the sample. It ought to be noted that in detecting overconfidence in a CEO, he/she is defined as being overconfident for all the relevant years. A dummy variable is established with 1 representing overconfidence and 0 otherwise.

To control company and governance attributes that influence the capital structure, the study adds the company size, profitability, dividends, sectors, board size, duality, board independence, board meeting, family ownership, managerial ownership, block holders and institutional ownership. Previous studies have suggested that these variables may affect the capital structure (e.g. Berger et al., 1997; Wen et al., 2002; Olokoyo, 2013). The following model investigates the relationship between capital structure and the CEO's characteristics. Table 3 provides the definitions and measurements of all variables. Equation (1) summarises the empirical model.

FLEVER $_{\text {it }}=\beta_{0}+\beta_{1}$ CAGE $+\beta_{2}$ CGEND $+\beta_{3}$ COVER $+\beta_{4}$ FSIZE $+\beta_{5}$ FPROFIT $+\beta_{6}$ FDIVID $+\beta_{7}$ FINDUST $+\beta_{8}$ BOARDSI $+\beta_{9}$ BOARDD $+\beta_{10}$ BOARDI $+\beta_{11}$ BOARDM $+\beta_{12}$ BOARDIN $+\beta_{13}$ MANAOW $+\beta_{14}$ FAMILOW $+\beta_{15}$ INSTITOW $+\beta_{16}$ BLOCKOW + Industry Controls + Year Controls $+\varepsilon_{1}$.

Where:

$\beta_{0}=$ The regression intercept; $\beta_{1} \ldots \beta 10=$ The regression coefficients; $\varepsilon=$ The error term.

Table 3. Variable definitions and measurements

\begin{tabular}{|c|c|c|}
\hline Label & Variable & Description \\
\hline FLEVER & Leverage Ratio & $\begin{array}{l}\text { Used as a proxy for capital structure measured by total long-term debt divided by } \\
\text { total assets. }\end{array}$ \\
\hline CAGE & CEO's Age & $\begin{array}{l}\text { Measured by the difference between the CEO's date of birth and the years of the } \\
\text { study period. }\end{array}$ \\
\hline
\end{tabular}




\begin{tabular}{|c|c|c|}
\hline Label & Variable & Description \\
\hline CGEND & CEO's Gender & A dummy variable taking value 1 if CEO male, and 0 if CEO female. \\
\hline COVER & $\begin{array}{l}\text { CEO's } \\
\text { Overconfidence }\end{array}$ & $\begin{array}{l}\text { Measured using: Net Buyer: dummy variable taking value } 1 \text { if the proportion of } \\
\text { CEO share ownership, options and stock exercise increases, and } 0 \text { otherwise. }\end{array}$ \\
\hline FSIZE & Firm Size & The natural log of a firm's total assets. \\
\hline FPROF & Firm Profitability & Measured by ROA (net income before tax divided by total assets). \\
\hline FDIVID & Dividends Ratio & Cash dividends divided by net income for the same period. \\
\hline FINDUST & Industry Type & $\begin{array}{l}\text { A dummy variable that takes the value of } 1 \text { in the company operates under } \\
\text { manufacturing sector and } 0 \text { if operates under service sector. }\end{array}$ \\
\hline BOARDSI & Board Size & Measured by the total numbers of the board. \\
\hline BOARDD & Board Duality & $\begin{array}{l}\text { A dummy variable that takes the value of one if the CEO and chairman are the } \\
\text { same person and zero otherwise. }\end{array}$ \\
\hline BBOARDM & Board Meeting & The number of meetings per year held by the board of directors. \\
\hline MANAOW & $\begin{array}{l}\text { Managerial } \\
\text { Ownership }\end{array}$ & $\begin{array}{l}\text { Measured by the proportion of total shares held by executive directors divided by } \\
\text { the total number of shares. }\end{array}$ \\
\hline FAMILOW & Family Ownership & $\begin{array}{l}\text { Measured by the proportion of total shares owned by the family. Dummy variable } \\
\text { takes } 1 \text { if a family or individual holds } 10 \% \text { or more of equity and } 0 \text { otherwise. }\end{array}$ \\
\hline INSTITOW & $\begin{array}{l}\text { Institutional } \\
\text { Ownership }\end{array}$ & $\begin{array}{l}\text { Measured by dummy variable would take one if any institutional-held shares and } \\
\text { zero otherwise. }\end{array}$ \\
\hline BLOCKOW & $\begin{array}{ll}\text { Block holder } \\
\text { Ownership }\end{array}$ & $\begin{array}{l}\text { A dummy variable that takes the value } 1 \text { if the firm has an external stockholder } \\
\text { owning } 5 \% \text { or more of the outstanding shares, and } 0 \text { otherwise. }\end{array}$ \\
\hline
\end{tabular}

\section{Results and Discussion}

\subsection{Descriptive Statistics}

Table 4 shows that the mean value of leverage ratio is (0.295), comprable to the $29 \%$ documented by Frank and Goyal (2009). However, the minimum and maximum values of leverage ratio are (0.002) and (0.978) respectively with a standard deviation (SD) of (0.2320). The mean age is 51.11 with a range from 26 to 84 , and the median value 51 . This result is comparable to previous studies, such as Custódio and Metzger (2014) and (Serfling 2014), both of whom observe an average age of 52. The median age is used as a cut-off point to classify older and younger CEOs. In addition, the descriptive result shows that $95 \%$ of the CEOs are male and $5 \%$ managed by female CEOs. These percentages are lower than in comparable studies by Huang and Kisgen (2013) and (Faccio et al. 2016), who document 6.2\% and 9.4\% respectively. Table 4 shows that $43 \%$ of CEOs were overconfident about their company's performance based on Net Buyer method.

In respect of the control variables, the company size value indicate that the companies are widely dispersed, ranging from 0.9303 to 3.2309 . The results reveal that profitability varies between minimum values of -85.90 percent (loss) and 95 percent (maximum profit), with SD 12.17 percent. Industry type has a 36.3 percent mean value with SD (48.11). In addition, Table 4 shows that the mean value of dividends ratio is 18.82 percent, minimum and maximum values are 0 and 97.51 percent respectively, and correspondingly the median value is zero ( $S D=30.77$ percent). Board size has a mean value 8.011 , which is relatively consistent with the number reported by (Peasnell et al., 2005). However, the maximum board size is 19 members, which indicates that, in general, Jordanian firms do not follow the Jordanian Corporate Governance Code number which recommends a maximum of 13 members (ASE, 2015). A dummy variable of board duality has a mean of 0.205, and board meeting number minimum and maximum values are 3 and 28 respectively. Board independence has a mean value 2.020 . In terms of ownership structure, managerial and family ownership have mean values of 0.352 and 0.19 respectively, while institutional and blockholder ownership have mean values of 0.355 and 0.435 respectively.

Table 4. Descriptive analysis

\begin{tabular}{lccccc}
\hline Variables & Observations & Minimum & Maximum & Mean & Std. Deviation \\
\hline FLEVER & 1206 & .0002 & .9780 & .295 & .232 \\
CAGE & 1206 & 26 & 84 & 51.41 & 11.26 \\
CGEND & 1206 & 0 & 1 & .9519 & .214 \\
COVER & 1206 & 0 & 1 & .435 & .491 \\
FSIZE & 1206 & .93 & 3.23 & 5.55 & 1.57
\end{tabular}




\begin{tabular}{|c|c|c|c|c|c|}
\hline Variables & Observations & Minimum & Maximum & Mean & Std. Deviation \\
\hline FPROFIT & 1206 & -.859 & .950 & .001 & .121 \\
\hline FSECTOR & 1206 & 0 & 1 & .363 & .481 \\
\hline FDIVID & 1206 & 0 & .9751 & .188 & .307 \\
\hline BOARDSI & 1206 & 3 & 19 & 8.01 & 2.44 \\
\hline BOARDD & 1206 & 0 & 1 & .205 & .404 \\
\hline BOARDM & 1206 & 3 & 28 & 7.57 & 2.13 \\
\hline BOARDI & 1206 & 0 & 8 & 2.02 & 1.23 \\
\hline MANAOW & 1206 & 0 & .7185 & .035 & .085 \\
\hline FAMILOW & 1206 & 0 & .945 & .190 & 27.20 \\
\hline INSTITOW & 1206 & 0 & 1 & .355 & .272 \\
\hline BLOCKOW & 1206 & 0 & 1 & .435 & .451 \\
\hline
\end{tabular}

\subsection{Multicollinearity}

A correlation coefficients matrix was used to check for the incidence of multicollinearity between independent variables, as employed extensively in previous disclosure literature (e.g. Abdel-Fattah, 2008; Alqatamin et al., 2017). Table 5 shows that the highest correlation is between the board size and board independence, with a coefficient of 41.54 percent. Therefore, Table 5 confirms that the multicollinearity problem does not exist in the data set used in this study.

\subsection{Regression Analysis}

To achieve investigate the relationship between CEOs' personal characteristics and capital structure choices, a panel regression random-effect method was used; the results are presented in Table 6 . The $R^{2}$ value is 71.6 percent, which means that the independent variable demonstrates 71.6 percent of the variation in the dependent variable. The $P$-value is highly significant at the level $(P>.000)$, meaning that the model is highly significant and thus has a good explanatory power of disclosure. The analysis of results shows a significant and positive relationship between CEOs' overconfidence and leverage ratio as a proxy for capital structure at the level $(P<.001)$. This result supports $H 1$, which suggested that there is a positive relationship between CEO overconfidence and debt level among non-financial Jordanian companies. Our results are consistent with the study of Fairchild's (2005) and Malmendier et al. (2011) who found a positive and significant relationship between CEOs' overconfidence and leverage ratio. This result indicates that the higher the level of leverage ratio, the higher will be the CEO's overconfidence, which suggests that specific personal characteristics of top management affect the decision-making process (Hambrick, 2007). A possible explanation for these findings is that overconfident managers are more likely to be more optimistic about future circumstances, overestimating their own abilities and issuing a high portion of debt. In respect to the CEO's age, we document a negative significant coefficient $(P<.006)$, which implies a significant relationship between the capital structure and the CEO's age. This result provides support for the prediction that younger CEOs are bolder and use riskier financing than older CEOs, which is consistent with the predictions of Serfling (2014), who reported that age is associated with debt financing behavior. The result also supports the prediction of Hambrick and Mason (1984) that older managers have less physical and mental stamina, and therefore value financial security and stability by reducing leverage. This finding is also consistent with several studies that reported a significant negative association between the CEO's age and other factors such as investment decision (Serfling, 2012; Yim, 2013). The results of our study indicate that older managers tend to avoid risks more than do younger managers; younger managers want to show their capability to stakeholders. Therefore, $\mathrm{H} 2$ is supported.

The third hypothesis is related to gender, that male CEOs take more risks than female and as a result, employ higher levels of debt. Therefore, the third regression result is for CEOs' gender. It scored a positive and significant relationship to firm leverage ratio at level $(\mathrm{P}<.001)$. Thus, $\mathrm{H} 3$ is supported. The finding indicates that companies managed by male CEOs are associated with a higher leverage ratio than those managed by female CEOs. The result suggests that males more confident and may even be overconfident. As a result, they are more likely to undertake more debt in the same operational conditions. Their confident in their management ability makes them believe that more debt would bring higher return. This finding confirms that gender diversity is one of the attributes influencing capital structure decisions. 
Table 5. Correlation Matrix

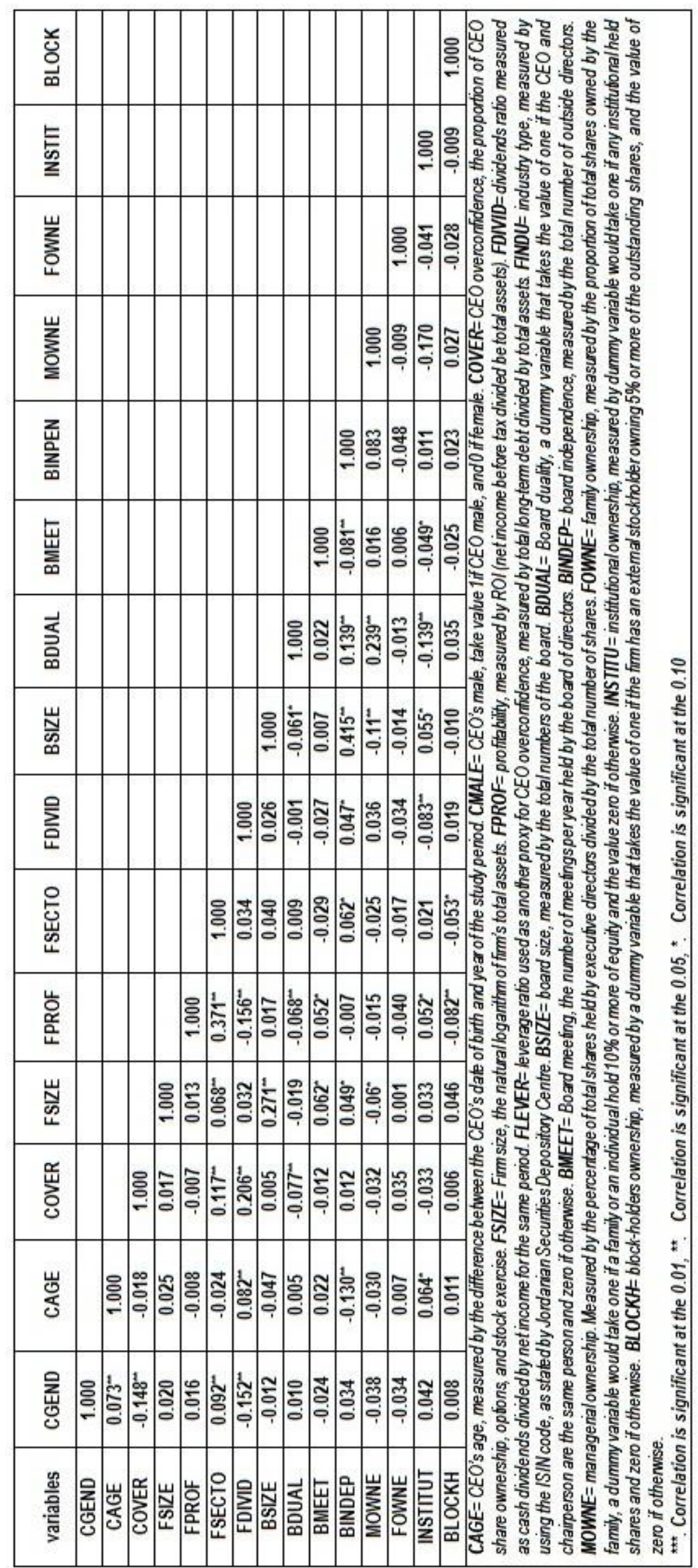


Hence, CEO gender is relevant to debt ratio choice in the Jordanian case. The reason may be that both genders in Jordanian non-financial companies follow the same family rules of the company, as much of Jordanian businesses are family oriented. Our results are in line with the upper echelon theory, that assumes males are overconfident and risk-tolerant while females are more conservative and risk-averse (Huang and Kisgen, 2013). The upper echelon theory also describes female CEOs as being more conservative, which corresponds to equity financing rather than debt financing (Frank and Goyal, 2007; Huang and Kisgen, 2013; Faccio et al., 2016).

With respect to a firm's characteristics and corporate governance factors as control variables, the coefficients of a firm's profitability and family ownership have a negative and significant association with leverage ratio as a proxy for capital structure. The study finds that more profitable companies require less external financing since they can rely to a greater degree on retained earnings (Myers and Majluf, 1984). This result is consistent with previous studies (e.g. King and Santor, 2008; Al-Fayoumi et al., 2010).

Table 6. Regression estimates for panel sample of companies, $\mathrm{N}=201$

\begin{tabular}{lcccc}
\hline \multicolumn{1}{c}{ Variables } & Predicted sign & Coeff. & t-stat. & P. Value \\
\hline Constant & + & .2067638 & 3.31 & $.001^{* * *}$ \\
COVER & + & .0973374 & 7.39 & $.001^{* * *}$ \\
CAGE & - & -.0015618 & -2.72 & $.006^{* * *}$ \\
CGEND & + & .1257617 & 3.88 & $.001^{* * *}$ \\
FSIZE & - & $3.85 e-11$ & .461 \\
FPROFIT & - & -.3025583 & -5.81 & $.000^{* * *}$ \\
FSECTOR & - & -.0036318 & -0.17 & .686 \\
FDIVID & - & .032575 & 1.54 & .123 \\
BOARDSI & $?$ & .0004294 & 0.10 & .918 \\
BOARDD & $?$ & -.0005617 & -0.03 & .980 \\
BOARDM & $?$ & -.0009713 & -0.29 & .775 \\
BOARDI & + & .0105255 & 1.32 & .187 \\
MANAOW & - & -.00247 & -0.03 & .980 \\
FAMILOW & -.000366 & -1.77 & $.076^{*}$ \\
BLOCKOW & + & -.0023372 & -0.20 & .840 \\
INSTITOW & + & .0105255 & 1.32 & .187 \\
Adjusted $R^{2}$ & $71.6 \%$ & & & \\
F-Stat. & $14.991^{* * *}$ & & & \\
\hline$* *$ Significant at the 0.01 level. ${ }^{* *}$ Significant at the 0.5 level. * Significant at the 0.10 level. & \\
\hline
\end{tabular}

\subsection{Dealing with endogeneity}

To address the endogeneity bias problem, the literature suggests two options; the use of instrumental variables (IV) (McKnight and Weir, 2009; Choi et al., 2010) and a simultaneous system equation (Hermalin and Weisbach, 1991; Cornett et al., 2008). This study used both Durbin and Hausman tests to check for bias in the endogenous and independent variables (Gujarati, 2003). The tests gave an X2 of $5.52 \%$ and $5.85 \%(P<.0169, P<.0179)$ respectively, which suggests that the null hypothesis is rejected. Both instrumental variable and two-stage regression were therefore used to control for the endogeneity and simultaneity problems. The results of the two-stage regression are presented in Table 7.

The coefficient of leverage ratio is positively and significantly $(p<.016)$ related to the CEO's overconfidence. This result is in line with those of the panel regression random effect model reported in Table 6. The coefficient of CEO's age is significant and negatively associated with Leverage ratio $(p<.001)$. The two-stage regression analysis shows similar results to the panel regression in Table 6, corroborating the results of Lin et al. (2014), who found a positive and simultaneous relation between CEO characteristics and internal control quality. The coefficient of leverage ratio is significant and positively $(P<.001)$ related to gender, which suggests that these results are consistent with the main findings in Table 6 . Regarding the control variables, the findings reported in Table 7 show similar results to those in Table 6, although, some values have greater significance in Table 7; nevertheless, the direction and significance of the association with capital structure remain the same. In summary, the instrumental variable two-stage model results are consistent with the primary results presented in Table 6, implying that the simultaneity problem between 
capital structure and CEO characteristics does not affect the main results of capital structure and other control variables.

Table 7. Instrumental variable two-stage regression model (using linear regression model)

\begin{tabular}{ccccc}
\hline Variables & Predicted sign & Coeff. & t-stat & P. Value \\
\hline Constant & + & .2858471 & 11.13 & 0.000 \\
COVER & + & -.0025205 & -2.40 & $0.016^{* * *}$ \\
CAGE & - & .1060139 & 4.70 & $0.001^{* * *}$ \\
CGEND & + & .3024688 & 6.64 & $0.001^{* * *}$ \\
FSIZE & - & $2.37 e-10$ & 6.51 & $0.001^{* * *}$ \\
FPROFIT & - & -.067299 & -1.64 & $0.101^{*}$ \\
FSECTOR & - & .0727807 & 4.30 & $0.000^{* * *}$ \\
FDIVID & - & $6.92 \mathrm{e}-12$ & 0.413 \\
BOARDSI & $?$ & .0040664 & 0.82 & $0.047^{* *}$ \\
BOARDD & $?$ & .0140643 & 1.99 & 0.237 \\
BOARDM & $?$ & -.0011452 & 1.18 & 0.584 \\
BOARDI & + & .005462 & -0.55 & 0.183 \\
MANAOW & - & -.0587541 & 1.33 & 0.285 \\
FAMILOW & - & -.0479093 & -1.07 & $0.012^{* * *}$ \\
BLOCKOW & + & -.0467553 & -2.51 & $0.006^{* * *}$ \\
INSTITOW & + & -.0008176 & -0.09 & 0.929 \\
R Sq. value & 0.781 & & &
\end{tabular}

${ }^{* *}$ Significant at the 0.01 level. ${ }^{* *}$ Significant at the 0.5 level. ${ }^{*}$ Significant at the 0.10 level.

\section{Conclusions}

The paper examined the effect of CEOs' characteristics on the capital structure in Jordanian listed companies during the period 2008 to 2013, motivated by findings reported in the literature that the financial reporting process varies predictably with individual characteristics of CEOs. We found that $95 \%$ of the sample was managed by male CEOs, and that most Jordanian companies are family-owned. The limited number of female CEOs, 5\%, still exceeds the averages of around $3 \%$ in Brazil, Botswana, Ireland, Japan, New Zealand and the UAE (Grant Thornton International Business Report, 2012). The overall results indicate that CEO overconfidence and gender have a positive and significant association with the capital structure. The regression further shows a significant negative association between the leverage ratio and CEOs' age, suggesting that older CEOs are less likely to acquire more debt than younger CEOs. The findings of the study should be of interest to policymakers, regulators and academics regarding the impact of CEO characteristics on the capital structure, not only in Jordan but also in other developing countries. Further, the findings of this study are likely to be of interest to investors, since this study introduces new empirical evidence about a company's capital structure in Jordan.

The results will also be of interest to shareholders, while police makers might find the findings to improve the performance of CEOs and their potential under-diversified influence in the top management team. The findings will also be relevant for practitioners (e.g. analysts, investors, and different claimants of the company); for those parties it could be relevant to know what kind of influence the CEO's characteristics have on capital structure outcomes, and how this varies with different levels of decisionmaking power. Information is valuable and knowing certain effects exist can help make governance practices more direct and effective. The results could be used to inform policy development initiatives for balancing CEO's decision-making power, as this study brings to light how CEO's personal characteristics effect leverage ratio. However, these findings are based on non-financial companies only, and future studies could focus on the financial sector, which plays an increasingly important role in developing economies, particularly Jordan, which is a bridgehead of market liberalisation in the Middle East North Africa region. At present, however, these results are not indicative of other countries, even within the Middle East, because of Jordan's unique liberalisation and other factors. 


\section{References}

1. Abdel-Fattah, T. M. H. (2008). Voluntary disclosure practices in emerging capital markets: The case of Egypt, University of Durham.

2. Ahmad, Z., N. M. H. Abdullah, and S. Roslan. (2012). Capital structure effect on firms performance: Focusing on consumers and industrials sectors on Malaysian firms. International Review of Business Research Papers 8 (5):137-155.

3. Al-Akra, M., and P. Hutchinson. (2013). Family firm disclosure and accounting regulation reform in the Middle East: The case of Jordan. Research in Accounting Regulation 25 (1):101-107.

4. Al-Fayoumi, N., B. Abuzayed, and D. Alexander. (2010). Ownership structure and earnings management in emerging markets: The case of Jordan. International Research Journal of Finance and Economics 38:28-47.

5. Alicke, M. D. (1985). Global self-evaluation as determined by the desirability and controllability of trait adjectives. Journal of Personality and Social Psychology 49 (6):1621.

6. Alqatamin, R., Z. Ali, and T. Arun. (2017). The effect of CEOs' characteristics on forward-looking information. Journal of Applied Accounting Research.

7. Alzoubi, E. S. S., and E. S. S. Alzoubi. (2016). Disclosure quality and earnings management: Evidence from Jordan. Accounting Research Journal 29 (4):429-456.

8. Andriosopoulos, D., K. Andriosopoulos, and H. Hoque. (2013). Information disclosure, CEO overconfidence, and share buyback completion rates. Journal of Banking \& Finance 37 (12):5486-5499.

9. ASE, A. S. E. M. Companies Control Department classification 2015 [cited.

10.Athanasakou, V., and K. Hussainey. (2014). The perceived credibility of forward-looking performance disclosures. Accounting and Business Research 44 (3):227-259.

11.Athanasakou, V. E., N. C. Strong, and M. Walker. (2009). Earnings management or forecast guidance to meet analyst expectations? Accounting and Business Research 39 (1):3-35.

12.Berger, P. G., E. Ofek, and D. L. Yermack. (1997). Managerial entrenchment and capital structure decisions. The journal of finance 52 (4):1411-1438.

13.Bertrand, M., and A. Schoar. (2003). Managing with style: The effect of managers on firm policies. The Quarterly Journal of Economics 118 (4):1169-1208.

14.Carpenter, M. A., M. A. Geletkanycz, and W. G. Sanders. (2004). Upper echelons research revisited: Antecedents, elements, and consequences of top management team composition. Journal of management 30 (6):749-778.

15.Chang, L. S., and K. S. Most. (1985). The perceived usefulness of financial statements for investors' decisions: University Presses of Florida Gainesville.

16.Chen, Y., X. Zhang, and Z. Liu. (2014). Manager Characteristics and the Choice of Firm "Low Leverage": Evidence from China. American Journal of Industrial and Business Management 4 (10):573.

17.Cooper, A. C., C. Y. Woo, and W. C. Dunkelberg. (1988). Entrepreneurs' perceived chances for success. Journal of business venturing 3 (2):97-108.

18.Cornett, M. M., A. J. Marcus, and H. Tehranian. (2008). Corporate governance and pay-forperformance: The impact of earnings management. Journal of financial economics 87 (2):357-373.

19.Cornett, M. M., J. J. McNutt, and H. Tehranian. (2009). Corporate governance and earnings management at large US bank holding companies. Journal of corporate finance 15 (4):412-430.

20.Cronqvist, H., A. K. Makhija, and S. E. Yonker. (2012). Behavioral consistency in corporate finance: CEO personal and corporate leverage. Journal of financial economics 103 (1):20-40.

21.Custódio, C., and D. Metzger. (2014). Financial expert CEOs: CEO's work experience and firm' s financial policies. Journal of financial economics 114 (1):125-154.

22.Davidson III, W. N., B. Xie, W. Xu, and Y. Ning. (2007). The influence of executive age, career horizon and incentives on pre-turnover earnings management. Journal of Management \& Governance 11 (1):45-60.

23.Desai, M. A., D. Dharmapala, and W. Fung. (2005). Taxation and the evolution of aggregate corporate ownership concentration: National Bureau of Economic Research.

24.Faccio, M., M.-T. Marchica, and R. Mura. (2016). CEO gender, corporate risk-taking, and the efficiency of capital allocation. Journal of corporate finance 39:193-209. 
25.Fairchild, R. (2010). Behavioural corporate finance: existing research and future directions. International Journal of Behavioural Accounting and Finance 1 (4):277-293.

26.Fairchild's, R. J. (2005). The effect of Managerial Overconfidence, asymmetric information, and moral hazard on capital structure decisions. Available at SSRN 711845.

27.Frank, M. Z., and V. K. Goyal. (2007). Corporate leverage: How much do managers really matter?

28.Frank, M. Z., and V. K. Goyal. (2009). Capital structure decisions: which factors are reliably important? Financial Management 38 (1):1-37.

29.Graham, J. R., C. R. Harvey, and M. Puri. (2013). Managerial attitudes and corporate actions. Journal of financial economics 109 (1):103-121.

30.Gujarati, D. (2003). Basic Econometrics Fourth Edition McGraw Hill Gujarati, DN. (2003). Basic Econometrics: McGraw Hill. International Edition.

31. Hackbarth, D. (2008). Managerial traits and capital structure decisions. Journal of Financial and Quantitative Analysis 43 (04):843-881.

32. Hambrick, D. C. (2007). Upper echelons theory: An update. Academy of management review 32 (2):334-343.

33. Hambrick, D. C., and P. A. Mason. (1984). Upper echelons: The organization as a reflection of its top managers. Academy of management review 9 (2):193-206.

34. Harris, M., and A. Raviv. (1991). The theory of capital structure. the Journal of Finance 46 (1):297355.

35. Hermalin, B. E., and M. S. Weisbach. (1991). The effects of board composition and direct incentives on firm performance. Financial management: 101-112.

36.Huang, J., and D. J. Kisgen. (2013). Gender and corporate finance: Are male executives overconfident relative to female executives? Journal of financial economics 108 (3):822-839.

37.JSC, J. S. C. (2015). General Information 2015 [cited 2-12 2015].

38.Katmun, N. (2012). Disclosure quality determinants and consequences, Durham University.

39.King, M. R., and E. Santor. (2008). Family values: Ownership structure, performance and capital structure of Canadian firms. Journal of Banking \& Finance 32 (11):2423-2432.

40.Kruger, J. (1999). Lake Wobegon be gone! The" below-average effect" and the egocentric nature of comparative ability judgments. Journal of Personality and Social Psychology 77 (2):221.

41.Landier, A., and D. Thesmar. (2009). Financial contracting with optimistic entrepreneurs. Review of financial studies 22 (1):117-150.

42.Langer, E. J. (1975). The illusion of control. Journal of Personality and Social Psychology 32 (2):311.

43.Lemmon, M., L. X. Liu, M. Q. Mao, and G. Nini. (2014). Securitization and capital structure in nonfinancial firms: An empirical investigation. The journal of finance 69 (4):1787-1825.

44.Li, T., Q. Munir, and M. R. A. Karim. (2017). Nonlinear relationship between CEO power and capital structure: Evidence from China's listed SMEs. International Review of Economics \& Finance 47:1-21.

45.Libby, R., and K. Rennekamp. (2012). Self-Serving Attribution Bias, Overconfidence, and the Issuance of Management Forecasts. Journal of accounting research 50 (1):197-231.

46.Lin, Y. C., Y. C. Wang, J. R. Chiou, and H. W. Huang. (2014). CEO Characteristics and Internal Control Quality. Corporate Governance: An International Review 22 (1):24-42.

47.Malmendier, U., and G. Tate. (2008). Who makes acquisitions? CEO overconfidence and the market's reaction. Journal of financial economics 89 (1):20-43.

48. Malmendier, U., G. Tate, and J. Yan. (2007). Corporate financial policies with overconfident managers: National Bureau of Economic Research.

49.Malmendier, U., G. Tate, and J. Yan. (2011). Overconfidence and early-life experiences: the effect of managerial traits on corporate financial policies. The Journal of Finance 66 (5):1687-1733.

50.Mason, E. S., and P. E. Mudrack. (1996). Gender and ethical orientation: A test of gender and occupational socialization theories. Journal of Business Ethics 15 (6):599-604.

51.Morellec, E. (2004). Can managerial discretion explain observed leverage ratios? The Review of Financial Studies 17 (1):257-294.

52.Myers, S. C., and N. S. Majluf. (1984). Corporate financing and investment decisions when firms have information that investors do not have. Journal of Financial Economics 13 (2):187-221. 
53.Olokoyo, F. O. (2013). Capital structure and corporate performance of Nigerian quoted firms: A panel data approach. African Development Review 25 (3):358-369.

54.Peasnell, K. V., P. F. Pope, and S. Young. (2005). Board monitoring and earnings management: do outside directors influence abnormal accruals? Journal of Business Finance \& Accounting 32 (7-8):13111346.

55.Richardson, G., G. Richardson, G. Taylor, G. Taylor, R. Lanis, and R. Lanis. (2016). Women on the board of directors and corporate tax aggressiveness in Australia: An empirical analysis. Accounting Research Journal 29 (3):313-331.

56.Ross, S. A. (1977). The determination of financial structure: the incentive-signalling approach. The Bell Journal of Economics: 23-40.

57.Salawu, R. O., and A. A. Agboola. (2008a). The determinants of capital structure of large nonfinancial listed firms in Nigeria.

58.Salawu, R. O., and A. A. Agboola. (20008b). The determinants of capital structure of large nonfinancial listed firms in Nigeria. The International Journal of Business and Finance Research 2 (2):75-84.

59.Serfling, M. A. (2012). CEO age, underinvestment, and agency costs. Eller College of Management, University of Arizona.

60.Serfling, M. A. (2014). CEO age and the riskiness of corporate policies. Journal of corporate finance 25:251-273.

61.Singh, A., and A. Zammit. (2000). International capital flows: Identifying the gender dimension. World Development 28 (7):1249-1268.

62.Skala, D. (2008). Overconfidence in psychology and finance-an interdisciplinary literature review. Bank i Kredyt (4):33-50.

63.Skalpe, O. (2007). The CEO gender pay gap in the tourism industry-Evidence from Norway. Tourism Management 28 (3):845-853.

64.Svenson, O. (1981). Are we all less risky and more skillful than our fellow drivers? Acta Psychologica 47 (2):143-148.

65.Tomak, S. (2013). The impact of overconfidence on capital structure in Turkey. International Journal of Economics and Financial Issues 3 (2):512-518.

66. Weinstein, N. D. (1980). Unrealistic optimism about future life events. Journal of personality and social psychology 39 (5):806.

67.Wen, Y., K. Rwegasira, and J. Bilderbeek. (2002). Corporate governance and capital structure decisions of the Chinese listed firms. Corporate Governance: An International Review 10 (2):75-83.

68.Yim, S. (2013). The acquisitiveness of youth: CEO age and acquisition behavior. Journal of financial economics 108 (1):250-273.

69.Yu, S., R. Lord, E. Peni, and S. Vähämaa. (2010). Female executives and earnings management. Managerial Finance 36 (7):629-645.

70.Zeitun, R., G. Tian, and S. Keen. (2007). Macroeconomic determinants of corporate performance and failure: evidence from an emerging market the case of Jordan.

71.Zeitun, R., and G. G. Tian. (2007). Capital structure and corporate performance: evidence from Jordan. Australasian Accounting, Business and Finance Journal 1 (4):3. 